\title{
Adsorptive removal of phenol and aniline by modified bentonite: adsorption isotherm and kinetics study
}

\author{
Shahin Ahmadi ${ }^{1}$. Chinenye Adaobi Igwegbe ${ }^{2}$
}

Received: 12 February 2018 / Accepted: 13 September 2018 / Published online: 21 September 2018

(c) The Author(s) 2018

\begin{abstract}
In the present study, the adsorptive potential of modified bentonite in a batch system for the removal of aniline and phenol from aqueous solutions was investigated. The effect of various parameters including contact time (10-120 min), $\mathrm{pH}(2-10)$, adsorbent dosage (0.4-1.5 g/L) and initial concentration of aniline and phenol (50-200 $\mathrm{mg} / \mathrm{L})$ was investigated in this experimental laboratory study. Maximum removal of aniline and phenol was achieved at contact time of 30 and 45 min for aniline and phenol, respectively, and at the lowest studied initial concentration of $50 \mathrm{mg} / \mathrm{L}$. Optimum bentonite dosage of 1 and $0.4 \mathrm{~g} / \mathrm{L}$ was obtained for phenol and aniline, respectively. The adsorption process was better at the $\mathrm{pH}$ of 6 for aniline and $\mathrm{pH}$ of 4 for phenol. It was found that the equilibrium data was best followed by the Langmuir and Freundlich isotherms. Also, the pseudo-second-order kinetic model was best applicable for phenol and aniline adsorption. It was defined that bentonite not only was an inexpensive absorbent, but also a quite effective adsorbent for the removal of aniline and phenol from water and wastewater.
\end{abstract}

Keywords Adsorption $\cdot$ Aqueous solution $\cdot$ Bentonite $\cdot$ Aniline $\cdot$ Phenol

\section{Introduction}

Organic compounds are used as intermediates for the manufacture of various synthetic compounds such as dyestuffs, rubbers, pesticides, plastics and paints (Ahmadi and Kord Mostafapour 2017a). The aniline can transform the hemoglobin into methaemoglobin causing anorexia, erythrocyte damage and spleen effect (Han et al. 2006; Matsushita et al. 2005). Phenol is considered as the priority pollutant since it is harmful to organisms even at a low concentration (Rahmani et al. 2008) due to its toxicity and carcinogenicity properties. Thus, it is fully recommended to remove phenol and aniline from industrial effluents before discharge to the water stream (Kord Mostafapoor et al. 2017). Several treatment methods have been proposed for the removal of aniline and phenol from contaminated waters, including

Shahin Ahmadi

sh.ahmadi398@gmail.com

1 Department of Environmental Health, Health Promotion Research Center, Zabol University of Medical Sciences, Zabol, Iran

2 Department of Chemical Engineering, Nnamdi Azikiwe University, Awka, Nigeria oxidation, biodegradation, chemical coagulation, solvent extraction, incineration, reverse osmosis and adsorption and other processes(Ahmadi et al. 2017a; Mozafarian et al. 2006; Taherkhani et al. 2015), among which adsorption is one of the most effective techniques in either laboratory or industrial scale (Ahmadi and Kord Mostafapour 2017b; Rodrigues et al. 2011). The highly used adsorbing materials are the active granulated carbons, but they are very expensive and not easily revived (Ciambelli et al. 1984).

Bentonite as a porous material exists in the environment in ease and abundance, and montmorillonite is the most important phase in it (Ahmadi et al. 2017b). It is a threelayered clay mineral composed of a silica and alumina. Its layers are not electrically neutral and have a negative charge. To overcome the electrical repulsion due to it, the negative charge is established between the layers and a series of positively charged cations fall between that layers, and they are called inter-layers cations (Liu and Zhang 2007). One of the methods for the activation of natural bentonite is activation by strong mineral acids. As a result of the contact between the montmorillonite and sulfuric acids, inter-layers cations are separated and proton is substituted. Activated bentonite is able to degrade a range of water contaminants and industrial wastewaters (Shen 
2002). For example, reduction of fluoride(Mahramanliglu et al. 2002), removal of paints (Özcan and Özcan 2004) and removal of organic compounds (Ahmadi and Kord Mostafapour 2017c) from industrial wastewater.

The adsorptive potential of modified bentonite in a batch system for the removal of aniline and phenol from aqueous solutions was investigated. The impact of various factors such as the contact time, adsorbent dosage, $\mathrm{pH}$ and initial concentration of aniline and phenol were studied and their optimum conditions were also determined. Finally, the adsorption experimental data were fitted into the adsorption isotherm and kinetic models.

\section{Materials and methods}

Aniline $\left(\mathrm{C}_{6} \mathrm{H}_{5} \mathrm{NH}_{2}\right)$ and phenol $\left(\mathrm{C}_{6} \mathrm{H}_{5} \mathrm{OH}\right)$ are aromatic compounds with molecular weights of $93.13 \mathrm{~g} / \mathrm{mol}$ and $94.11 \mathrm{~g} / \mathrm{mol}$, respectively; they were purchased from Sigma-Aldrich Co, Germany. Their stock solutions $(1000 \mathrm{mg} / \mathrm{L})$ were prepared, and the desired concentrations of aniline and phenol solutions were prepared by dilution of the prepared stock solution. The chemical structures of aniline and phenol are shown in Fig. 1.

\section{Characterization of the adsorbent}

The acid-modified bentonite was synthesized by the following steps. First, the bentonite (clay) was obtained from Zahedan, Iran (Longitude: $29^{\circ} 29^{\prime} 46.68^{\prime \prime} \mathrm{N}$, Latitude: $\left.60^{\circ} 51^{\prime} 46.44^{\prime \prime} \mathrm{E}\right)$. Bentonite was washed thoroughly with distilled water and dried at $105{ }^{\circ} \mathrm{C}$ for $24 \mathrm{~h}$. A total of 15 $\mathrm{gr}$ of bentonite was activated by using $20 \mathrm{ml}$ of sulfuric acid for $24 \mathrm{~h}$. Then, it was rinsed thrice with distilled water and dried at $110^{\circ} \mathrm{C}$ for $1 \mathrm{~h}$. After that, the clay was ground and sieved using a 100-mesh sieve. The chemical compopresented in Table 1. sition of the bentonite was obtained through XRF and is

Table 1 The chemical composition of bentonite

\begin{tabular}{lllll}
\hline Bentonite & $\mathrm{SiO}_{2}$ & $\mathrm{Al}_{2}\left(\mathrm{SO}_{4}\right) 16 \mathrm{H}_{2} \mathrm{O}$ & $\begin{array}{l}\mathrm{Na}(\mathrm{Al}, \mathrm{Mg})_{2} \\
\mathrm{Si}_{4} \mathrm{O}_{10}(\mathrm{OH})_{2} . \\
2 \mathrm{H}_{2} \mathrm{O}\end{array}$ & $\begin{array}{l}\mathrm{Na}-\mathrm{Ca}-\mathrm{AL}- \\
\mathrm{Mg}-\mathrm{Si}-\mathrm{O}-\mathrm{H}_{2} \mathrm{O}\end{array}$ \\
\hline $\mathrm{W}(\%)$ & 25 & 29 & 9 & 10.1 \\
\hline
\end{tabular}

\section{Batch adsorption experiments}

The most effective factors for adsorption process, including contact time (10-105 min), $\mathrm{pH}(2,4,6,8$, and 10), adsorbent dose $(0.4-1.5 \mathrm{~g} / \mathrm{L})$ and initial concentration of aniline and phenol $(50-150 \mathrm{mg} / \mathrm{L})$ were assessed on aniline and phenol removal. The optimum $\mathrm{pH}$ was determined by varying the $\mathrm{pH}$ in the range of 2-10 and keeping other variables constant (contact time, adsorbent dose and initial aniline and phenol concentration). The experiments were performed in a100-mL beaker with a constant concentration of aniline and phenol. Then, this mixture was shaken with a shaker device of enforcing model with $150 \mathrm{rpm}$ at temperatures between 20 and $25^{\circ} \mathrm{C} .0 .1 \mathrm{~N} \mathrm{HCl}$ and $\mathrm{NaOH}$ were used to adjust the of the $\mathrm{pH}$ solution. The final aniline and phenol concentration in solution were measured using a UV-visible spectrophotometer at wavelengths of 198 and $500 \mathrm{~nm}$, respectively (Rahdar and Ahmadi 2017; Ahmadi et al. 2017b).

The removal efficiency (RE) and sorption capacity $\left(q_{\mathrm{e}}\right)$ of the bentonite were determined applying Eqs. (1) and (2), respectively(Ahmadi et al. 2017c):

$\% \mathrm{RE}=\frac{\left(C_{0}-C_{\mathrm{f}}\right)}{C_{0}} \times 100$

$q_{\mathrm{e}}=\left(C_{0}-C_{\mathrm{e}}\right) \times \frac{V}{M}$

where $\mathrm{RE}(\%)$ and $q_{\mathrm{e}}(\mathrm{mg} / \mathrm{g})$ are the removal efficiency and adsorption capacity, respectively. $C_{0}(\mathrm{mg} / \mathrm{L})$ is the initial concentration, $C_{\mathrm{e}}(\mathrm{mg} / \mathrm{L})$ is the concentration at the equilibrium, $m(\mathrm{~g})$ is the mass of the adsorbent and $V(\mathrm{~L})$ is the volume of the solution.

\section{Results and discussion}

\section{Effect of pH}
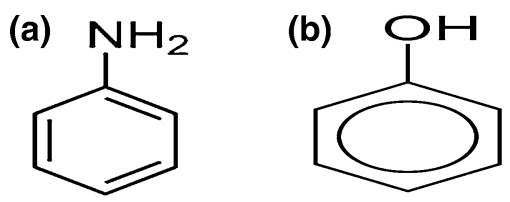

Fig. 1 The chemical structures of $\mathbf{a}$ aniline and $\mathbf{b}$ phenol
The $\mathrm{pH}$ value of the solution is an important controlling parameter in the adsorption process, as can be seen from Fig. 2 and Table 2. The effect of $\mathrm{pH}$ on aniline and phenol uptake in the batch process was studied by varying the $\mathrm{pH}$ from 2 to 10. Figure 2 and Table 2 show that the adsorption 


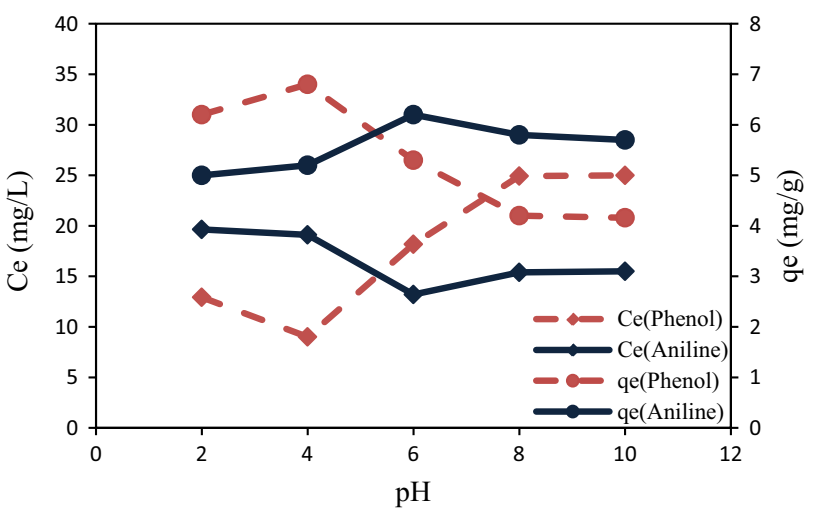

Fig. 2 Effect of $\mathrm{pH}$ on removal efficiency of pollutants by bentonite (contact time $=60 \mathrm{~min}$, dosage $=0.6 \mathrm{~g} / \mathrm{L}$, aniline and phenol concentration $=100 \mathrm{mg} / \mathrm{L}$ )

Table 2 Effect of initial $\mathrm{pH}$ on aniline and phenol removal by bentonite

\begin{tabular}{lcll}
\hline Adsorbate & Initial $\mathrm{pH}$ & $C_{\mathrm{e}}(\mathrm{mg} / \mathrm{L})$ & $Q_{\mathrm{e}}(\mathrm{mg} / \mathrm{g})$ \\
\hline Aniline & 2 & 19.65 & 5 \\
& 4 & 19.1 & 5.2 \\
& 6 & 13.3 & 6.2 \\
& 8 & 15.4 & 5.8 \\
Phenol & 10 & 15.5 & 5.7 \\
& 2 & 12.93 & 6.2 \\
& 4 & 9 & 6.8 \\
& 6 & 18.17 & 5.3 \\
& 8 & 24.93 & 4.2 \\
& 10 & 25 & 4.16 \\
\hline
\end{tabular}

of aniline and phenol at contact time of 60 min were maximum at $\mathrm{pH}$ values of 6 and 4, respectively. Aniline is a weak base and anionic in nature that changes to positively charged anilinium ion under acidic conditions. The influence of $\mathrm{pH}$ also depends on the point zero charge $\left(\mathrm{pH}_{\mathrm{ZPC}}\right)$ of the adsorbent and protonation constant $\left(\mathrm{p} K_{\mathrm{a}}\right)$. The point of zero charge is the point where the charge on catalyst surface is zero (Ahmadi et al. 2017b; Rahdar et al. 2018). $\mathrm{p} K_{\mathrm{a}}$ value for aniline is 4.6; phenol is a weak acid compound with $\mathrm{p} K_{\mathrm{a}} \approx 9.5$ (Rahdar and Ahmadi 2017; Kord Mostafapoor et al. 2017). At a $\mathrm{pH}$ value less than the $\mathrm{pH}_{\mathrm{ZPC}}$ of bentonite (which was obtained as 4.6), the surface of the bentonite had a positive charge. In acidic $\mathrm{pH}$, electrostatic attraction between the pollutants' negative and bentonite positive charge increased; therefore, the efficiency of removal increased (El-Latif et al. 2010). The adsorbent surface better adsorbs anion at low $\mathrm{pH}$ values and in the presence of $\mathrm{H}^{+}$ ions. In alkali $\mathrm{pH}$ conditions, the concentration of $\mathrm{OH}^{-}$ions increase; therefore, competition between them and anions increase. The efficiency of removal decreases because of the

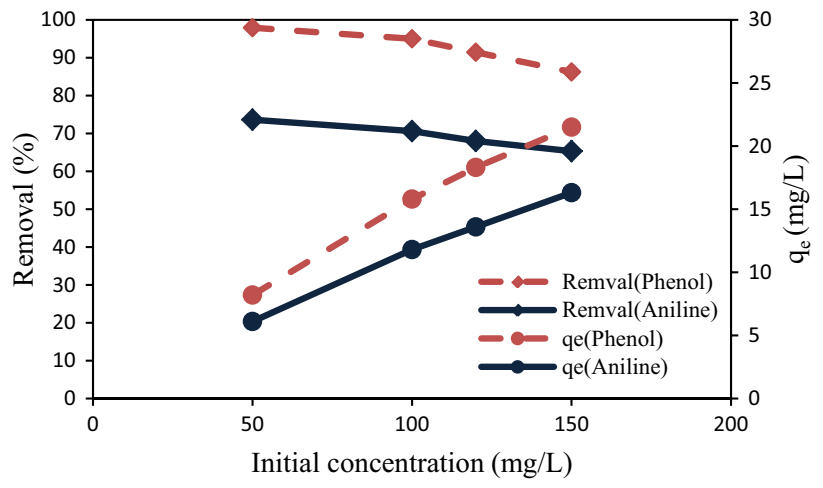

Fig. 3 Effect of initial concentration on removal efficiency of pollutants by bentonite (time $=60 \mathrm{~min}$, dosage $=0.6 \mathrm{~g} / \mathrm{L}$, optimum $\mathrm{pH}$ )

Table 3 Effect of initial concentration on aniline and phenol removal by bentonite

\begin{tabular}{lccl}
\hline Adsorbate & $\begin{array}{l}\text { Initial concentration, } \\
C_{0}(\mathrm{mg} / \mathrm{L})\end{array}$ & $Q_{\mathrm{e}}(\mathrm{mg} / \mathrm{g})$ & $\%$ Removal \\
\hline Aniline & 50 & 6.1 & 73.6 \\
& 100 & 11.8 & 70.6 \\
& 120 & 13.6 & 67.99 \\
& 150 & 16.3 & 65.3 \\
Phenol & 50 & 8.2 & 97.9 \\
& 100 & 15.8 & 95 \\
& 120 & 18.3 & 91.6 \\
& 150 & 21.5 & 86.2 \\
\hline
\end{tabular}

repulsive force of negative charges of bentonite and pollutants (Zhong et al. 2010).

\section{Effect of initial concentration}

To determine the effect of initial aniline and phenol concentration on the adsorption process, the initial concentrations of aniline and phenol were varied from 50 to $150 \mathrm{mg} / \mathrm{L}$ at the optimum $\mathrm{pH}$, adsorbent dose of $0.6 \mathrm{~g} / \mathrm{L}$ and contact time of $60 \mathrm{~min}$. As presented in Fig. 3 and Table 3, aniline and phenol removal efficiency decreased with increasing initial concentration, so maximum efficiency was achieved at the initial concentration of $50 \mathrm{mg} / \mathrm{L}$. As a result, the adsorption rate decreases, this may be owing to the finite number of active sites on the adsorbent that becomes saturated at high concentration of aniline and phenol (Sui et al. 2011).

\section{Effect of adsorbent dose}

The effect of adsorbent dose on the removal of aniline and phenol was studied by varying the dose of adsorbent from 0.4 to $1.5 \mathrm{~g} / \mathrm{L}$ (Fig. 4 and Table 4 ). The percentage of phenol 


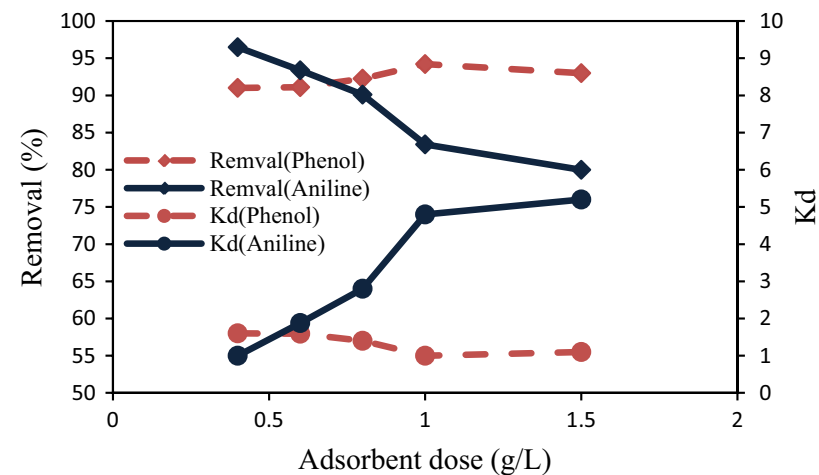

Fig. 4 Effect of adsorbent dose on removal efficiency of pollutants by bentonite (contact time $=60 \mathrm{~min}, \mathrm{pH}=6$, pollutants concentration $=50 \mathrm{mg} / \mathrm{L}$ )

Table 4 Effect of adsorbent dose on aniline and phenol removal by bentonite

\begin{tabular}{llll}
\hline Adsorbate & $\begin{array}{l}\text { Adsorbent dose } \\
(\mathrm{g} / \mathrm{L})\end{array}$ & $\%$ Removal & $K_{\mathrm{d}}\left(C_{\mathrm{e}} / C_{0}\right)$ \\
\hline Aniline & 0.4 & 96.48 & 1 \\
& 0.6 & 93.37 & 1.88 \\
& 0.8 & 90.1 & 2.8 \\
& 1 & 83.34 & 4.8 \\
& 1.5 & 80 & 5.2 \\
Phenol & 0.4 & 91 & 1.6 \\
& 0.6 & 91.1 & 1.59 \\
& 0.8 & 92.24 & 1.4 \\
& 1 & 94.2 & 1 \\
& 1.5 & 93 & 1.1 \\
\hline
\end{tabular}

removal steeply increased with the adsorbent loading up to $1 \mathrm{~g} / \mathrm{L}$, but aniline adsorbed decrease as the dose of adsorbent increases from 0.4 to $1 \mathrm{~g} / \mathrm{L}$; this indicates that increase in the adsorbent dose lead to the decrease in the efficiency of aniline which may be as a result of the decrease in the active surface of the adsorbent (Ahmadi and Kord Mostafapour 2017a). The increased adsorption of phenol by increasing the amount of adsorbent is as a result of an increase in the active sites and effective surface in the adsorbent (Sui et al. 2011).

\section{Effect of contact time}

Figure 5 and Table 5 show the effect of contact time on $C_{\mathrm{e}}$ and percent removal efficiency of aniline and phenol onto the modified bentonite at a constant initial concentration $(50 \mathrm{mg} / \mathrm{L})$ and optimum adsorbent dosage and optimum $\mathrm{pH}$. The uptake of aniline on the modified bentonite was rapid in the first $30 \mathrm{~min}(97.3 \%)$, but the uptake of phenol on the modified bentonite was rapid in the first $45 \mathrm{~min}(95.3 \%)$

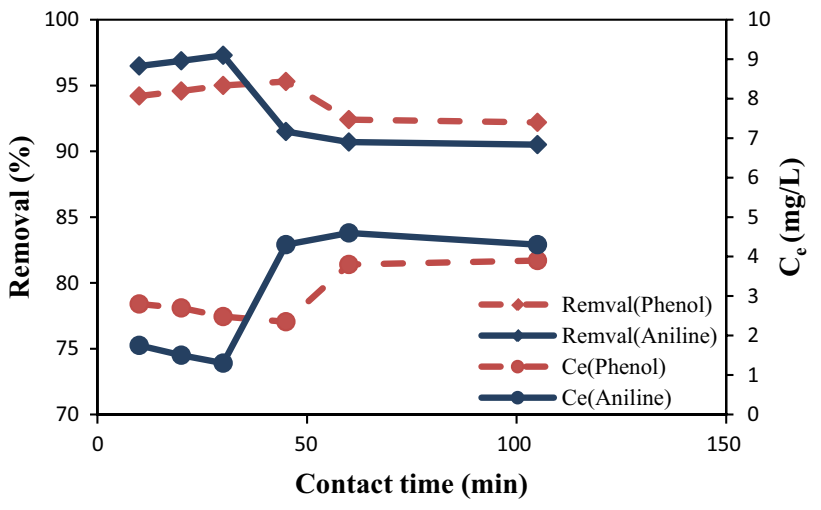

Fig. 5 Effect of contact time on removal efficiency of pollutants by bentonite $(\mathrm{pH}=6$, dosage $=1 \mathrm{~g} / \mathrm{L}$, pollutants concentration $=50 \mathrm{mg} / \mathrm{L}$ )

and then the adsorption rate decreased gradually and finally reached equilibrium. The increase in contact time from 10 to $30 \mathrm{~min}$ resulted in the increase in aniline adsorption, and the increase in contact time from 10 to 45 min resulted in the increase in phenol adsorption, because of more frequency of collisions between pollutants and adsorbent. Increasing the retention time resulted in more collision, which increased the pollutant adsorption by the adsorbent. Then, the adsorption process was slow as the time was increased further. This result can be supported by the results of the study (Mohanty et al. 2005).

\section{Adsorption isotherm}

The Langmuir isotherm is based on single layer and homogenous adsorbed material with the same energy on the surface. Freundlich isotherm was calculated using a heterogeneous surface with non-uniform distribution of surface absorption heat. The Freundlich isotherm is shown by Eq. 3 (Sui et al. 2011):

$\log \left(q_{\mathrm{e}}\right)=\log \left(K_{\mathrm{f}}\right)+\frac{1}{n} \log \left(C_{\mathrm{e}}\right)$

where $q_{\mathrm{e}}$ is the amount of aniline and phenol adsorbed $(\mathrm{mg} / \mathrm{g}), C_{\mathrm{e}}$ is the equilibrium concentration of aniline and phenol in solution $(\mathrm{mg} / \mathrm{L})$, and $K_{f}$ and $n$ are the constants incorporating the factors affecting the adsorption capacity and intensity of adsorption, respectively.

The Langmuir isotherm model is presented as Eq. 4 (Sui et al. 2011; Kakavandi et al. 2013):

$C_{\mathrm{e}} / q_{\mathrm{e}}=1 / q_{\mathrm{m}} K_{\mathrm{L}}+C_{\mathrm{e}} / q_{\mathrm{m}}$

where $q_{\mathrm{m}}$ (maximum adsorption capacity) is a monolayer adsorption capacity $(\mathrm{mg} / \mathrm{g}), q_{\mathrm{e}}$ is the amount of pollutant adsorbed on the adsorbent $(\mathrm{mg} / \mathrm{g})$ and $K_{\mathrm{L}}$ is Langmuir 
isotherm constant related to the affinity of the binding sites and energy of adsorption $(\mathrm{L} / \mathrm{mg})$. The essential specifications of a Langmuir isotherm can be expressed as the idiom of a dimensionless constant separation factor or equilibrium parameter, $R_{\mathrm{L}}$, which is defined by Eq. 5 (Mohanty et al. 2005):

$R_{\mathrm{L}}=\frac{1}{1+\mathrm{K}_{\mathrm{L}} \mathrm{C}_{0}}$

The $R_{\mathrm{L}}$ value indicates whether the process is unfavorable $\left(R_{\mathrm{L}}>1\right)$, linear $\left(R_{\mathrm{L}}=1\right)$ or favorable $\left(0<R_{\mathrm{L}}<1\right)$ (Igwegbe et al. 2016).

\section{Adsorption kinetics}

The rate of an adsorption process is elucidated through adsorption kinetic models (Balarak et al. 2016). The kinetics of adsorption depends on the chemical and physical properties of the adsorbent (Kilic et al. 2011). Linear equations relating to kinetics are shown as follows (pseudo-secondorder, pseudo-first-order and intraparticle diffusion model):

The pseudo-first-order rate equation is defined as in Eq. 6 (Sui et al. 2011):

$\log \left(q_{\mathrm{e}}-q_{t}\right)=\log q_{\mathrm{e}}-\frac{k_{1}}{2.303} t$

where $q_{\mathrm{t}}$ and $q_{\mathrm{e}}$ is the amount of adsorbate adsorbed at time $t$ and at equilibrium $(\mathrm{mg} / \mathrm{g})$, respectively, and $k_{1}$ is the pseudofirst-order rate constant for the adsorption process $\left(\mathrm{min}^{-1}\right)$.

The pseudo-second-order model can be represented in the following form (Mahvi and Heibati 2009):

$\frac{t}{q_{t}}=\frac{1}{K_{2} q_{\mathrm{e}}^{2}}+\frac{t}{q_{\mathrm{e}}}$

where $K_{2}$ is the pseudo-second-order rate constant ( $\mathrm{g} \mathrm{mg}^{-1} \mathrm{~min}^{-1}$ ), $q$ and $q_{\mathrm{e}}$ is the amount of the pollutant adsorbed on the adsorbent $(\mathrm{mg} / \mathrm{g})$ at equilibrium and at time $t$, respectively.

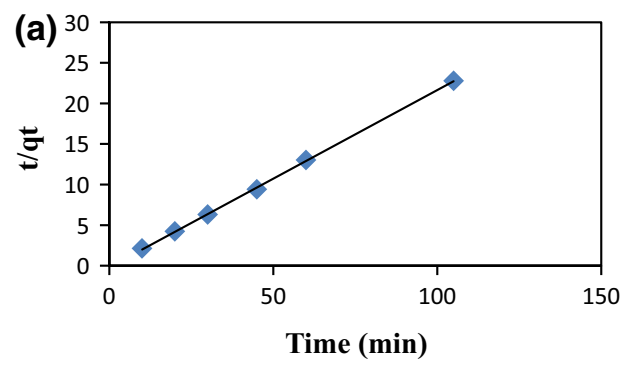

Table 5 Effect of contact time on aniline and phenol removal by bentonite

\begin{tabular}{lcll}
\hline Adsorbate & $\begin{array}{l}\text { Contact time } \\
(\mathrm{min})\end{array}$ & $\mathrm{C}_{\mathrm{e}}(\mathrm{mg} / \mathrm{L})$ & \% Removal \\
\hline Aniline & 10 & 1.75 & 96.48 \\
& 20 & 1.5 & 96.87 \\
& 30 & 1.3 & 97.3 \\
& 45 & 4.3 & 91.5 \\
& 60 & 4.6 & 90.7 \\
Phenol & 105 & 4.3 & 90.5 \\
& 10 & 2.8 & 94.2 \\
& 20 & 2.7 & 94.58 \\
& 30 & 2.48 & 95 \\
& 45 & 2.35 & 95.3 \\
& 60 & 3.8 & 92.4 \\
& 105 & 3.9 & 92.2 \\
\hline
\end{tabular}

The intraparticle diffusion model is given by Eq. 8 (Khoshnamvand et al. 2017):

$q_{t}=K_{i d} t^{0.5}+c$

where $c$ is a constant and the $k_{\text {id }}$ is the intraparticle diffusion rate constant $\left(\mathrm{mg} / \mathrm{g} \min ^{1 / 2}\right), q_{\mathrm{t}}$ is the amount adsorbed $(\mathrm{mg} / \mathrm{g})$ at time $t(\min )$.

The adsorption kinetic and isotherm parameters are shown in Tables 6 and 7. The results showed that aniline on bentonite fits best into the Freundlich isotherm model $\left(R^{2}=0.99\right)$, but phenol on bentonite fits best into the Langmuir model isotherm model $\left(R^{2}=0.997\right)$. In the two cases of isotherms, high correlation coefficient was obtained and this reflects the consistency of the results of this study with the Langmuir and Freundlich isotherms (Figs. 7, 8). $R_{\mathrm{L}}$ and $n$ represent the desirability of the isotherm. The adsorption of aniline and phenol on the adsorbent (bentonite) is favorable since $0<R_{\mathrm{L}}<1$ (Table 6).

The $R^{2}$ of the kinetic models (Fig. 6) suggest that the pseudo-second-order model mechanism is predominant which means that the uptake process follows the pseudosecond-order expression with correlation coefficients

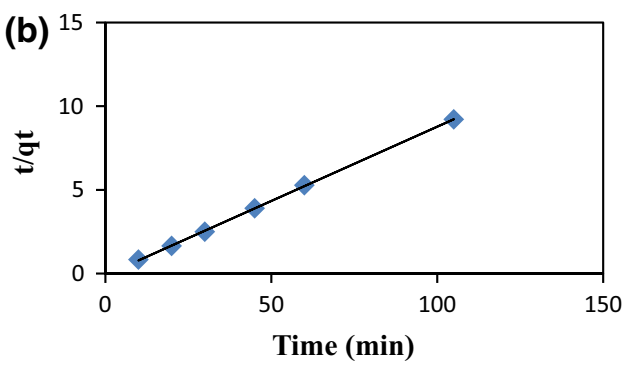

Fig. 6 Pseudo-second-order kinetic plot on $\mathbf{a}$ aniline and $\mathbf{b}$ phenol removal by bentonite 
Table 6 The adsorption isotherms constants for aniline and phenol adsorption

\begin{tabular}{llllllllll}
\hline & \multicolumn{2}{l}{ Freundlich isotherm } & & & \multicolumn{3}{l}{ Langmuir isotherm } \\
\cline { 2 - 4 } \cline { 7 - 9 } & $q_{0}\left(\frac{m g}{g}\right)$ & $k_{l}\left(\frac{l}{m g}\right)$ & $R_{\mathrm{L}}$ & & $R^{2}$ & & $K_{f}$ & $n$ & $R^{2}$ \\
\hline Phenol & 23.64 & 0.43 & 0.044 & 0.997 & & 8.6 & 3.12 & 0.97 \\
Aniline & 37.04 & 0.015 & 0.57 & & 0.987 & & 0.977 & 1.39 & 0.99 \\
\hline
\end{tabular}

Table 7 The adsorption kinetic model constants for aniline and phenol adsorption

\begin{tabular}{|c|c|c|c|c|c|c|c|c|c|}
\hline \multirow[t]{2}{*}{$\begin{array}{l}C_{0}(\mathrm{mg} / \mathrm{L}) \\
50\end{array}$} & \multicolumn{3}{|c|}{ Pseudo-second-order } & \multicolumn{3}{|c|}{ Pseudo-first-order } & \multicolumn{3}{|c|}{$\begin{array}{l}\text { Intraparticle diffu- } \\
\text { sion }\end{array}$} \\
\hline & $K_{2}(\mathrm{~g} / \mathrm{mg} \min )$ & $\mathrm{R}^{2}$ & $Q_{\mathrm{e}}(\mathrm{mg} / \mathrm{g})$ & $K_{1(1 / \mathrm{min})}$ & $R^{2}$ & $Q_{\mathrm{e}}(\mathrm{mg} / \mathrm{g})$ & $K_{\mathrm{pi}}$ & $C$ & $R^{2}$ \\
\hline Phenol & 0.05 & 0.999 & 4.58 & 0.016 & 0.46 & 0.033 & 0.09 & 4.8 & 0.388 \\
\hline Aniline & 0.01 & 0.999 & 11.26 & 0.02 & 0.56 & 0.157 & 0.13 & 12.5 & 0.603 \\
\hline
\end{tabular}
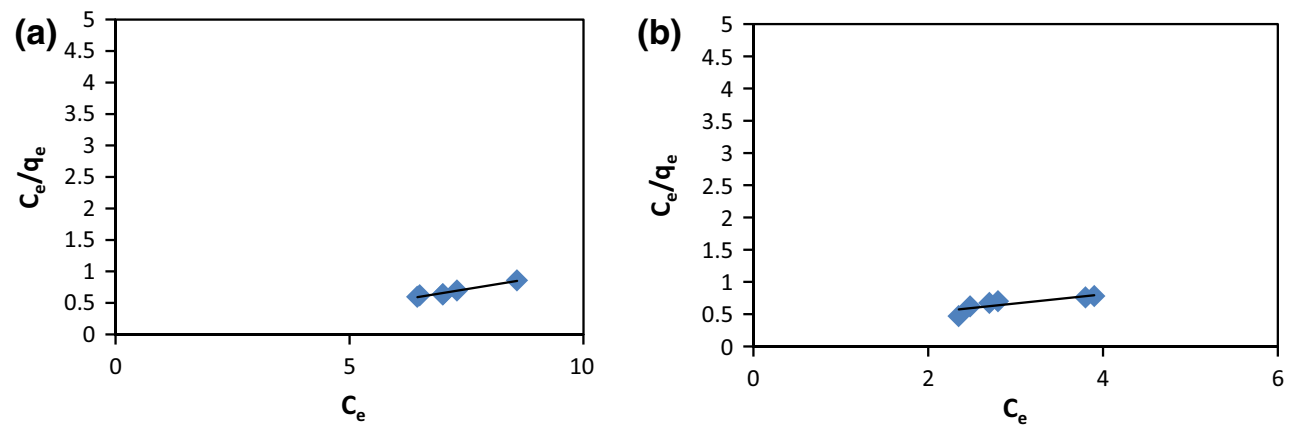

Fig. 7 Langmuir isotherm plot on a aniline and $\mathbf{b}$ phenol removal by bentonite
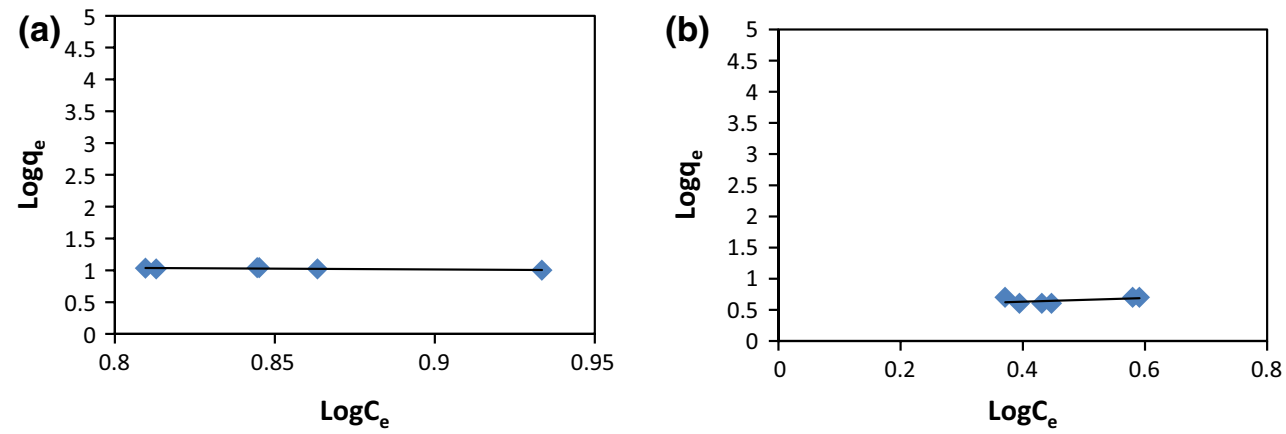

Fig. 8 Freundlich isotherm plot on $\mathbf{a}$ aniline and $\mathbf{b}$ phenol removal by bentonite

greater than 0.999. According to the kinetic coefficients, the obtained data follows the pseudo-second-order model and it's the best model to determine reaction rate that reflects the rapid adsorption of phenol and aniline. This proposes that the rate-limiting step is chemisorption (Igwegbe et al. 2016; Al-Ghouti et al. 2005). It is consistent with other studies (Rahdar and Ahmadi 2017; Ahmadi and Kord Mostafapour 2017a). 


\section{Conclusions}

The adsorptive potential of modified bentonite for the removal of aniline and phenol from aqueous solutions has been examined. Highest removal was achieved at contact time of 30 and 45 min for aniline and phenol, respectively; it was found to decrease as the initial concentration was increased for both adsorbates. The removal of aniline was maximum at $\mathrm{pH}$ of 6 and adsorbent dosage of $0.4 \mathrm{~g} / \mathrm{L}$ whereas for phenol, maximum removal was achieved at $\mathrm{pH} 4$ and dosage of $1 \mathrm{~g} / \mathrm{L}$. The process of aniline and phenol adsorption on modified bentonite conformed to the Freundlich and Langmuir isotherms with regards to their correlation coefficients, $R^{2}$. The kinetic data of aniline and phenol adsorption on modified bentonite followed the pseudo-second-order model. The experimental study shows that the modified bentonite by sulfuric acid can give good efficiency for the removal of aniline and phenol.

Acknowledgements The authors are grateful to the Zahdan University of Med-ical Sciences for the financial support in this study.

Open Access This article is distributed under the terms of the Creative Commons Attribution 4.0 International License (http://creativeco mmons.org/licenses/by/4.0/), which permits unrestricted use, distribution, and reproduction in any medium, provided you give appropriate credit to the original author(s) and the source, provide a link to the Creative Commons license, and indicate if changes were made.

\section{References}

Ahmadi S, Kord Mostafapour F (2017a) Adsorptive removal of aniline from aqueous solutions by Pistacia Atlantica (Baneh) shells: isotherm and kinetic studies. J Sci Technol Environ Inf 5:327-335. https://doi.org/10.18801/jstei.050117.35

Ahmadi S, Kord Mostafapour F (2017b) Adsorptive removal of bisphenol A from aqueous solutions by Pistacia Atlantica: isotherm and kinetic studies. Pharm Chem J 4:1-8

Ahmadi S, Kord Mostafapour F (2017c) Treatment of textile wastewater using a combined coagulation and DAF processes, Iran, 2016. Arch Hyg Sci 6:229-234

Ahmadi S, Kord Mostafapour F, Bazrafshan E (2017a) Removal of aniline from aqueous solutions by coagulation/flocculation-flotation. Chem Sci Int J 1:1-10. https://doi.org/10.9734/CSIJ/2017/32016

Ahmadi S, Bazrafshan E, Kord Mostafapour F (2017b) Treatment of landfill leachate using a combined coagulation and modify bentonite adsorption processes. J Sci Eng Res 4:58-64

Ahmadi S, Banach A, Mostafapour FK, Balarak D (2017c) Study survey of cupric oxide nanoparticles in removal efficiency of ciprofloxacin antibiotic from aqueous solution: adsorption isotherm study. Desalin Water Treat 89:297-303. https://doi.org/10.5004/ dwt.2017.21362

Al-Ghouti M, Khraisheh MAM, Ahmad MNM, Allen S (2005) Thermodynamic behavior and the effect of temperature on the removal of dyes from aqueous solution using modified diatomite: a kinetic study. J Colloid Interface Sci 287:6-13. https://doi.org/10.1016/j. jcis.2005.02.002
Balarak D, Bazrafshan E, Kord Mostafapour F (2016) Equilibrium, kinetic studies on the adsorption of acid green 3 (Ag3) Dye onto Azolla filiculoides as adsorbent. Am Chem Sci J 11:1-10. https:// doi.org/10.9734/ACSJ/2016/22048

Ciambelli P, Corbo P, Lumare F, Porcelli C (1984) In zeo-agriculture: use of natural zeolite in agriculture and aquaculture. Anim Sci $31: 25-42$

El-Latif MMA, Ibrahim AM, El-Kady MF (2010) Adsorption equilibrium, kinetics and thermodynamics of methylene blue from aqueous solutions using biopolymer oak sawdust composite. J Am Sci 6:267-283

Han Y, Quan X, Chen S, Zhao H, Cui C, Zhao Y (2006) Electrochemically enhanced adsorption of aniline on activated carbon fibers. Sep Purify Technol 50:365-372. https://doi.org/10.1016/j.seppu r.2005.12.011

Igwegbe CA, Onukwuli OD, Nwabanne JT (2016) Adsorptive removal of vat yellow 4 on activated Mucuna pruriens (velvet bean) seed shells carbon. Asian J Chem Sci 1:1-16. https://doi.org/10.9734/ AJOCS/2016/30210

Kakavandi B, Jonidi AJ, Rezaei RK, Nasseri S, Ameri A, Esrafili A (2013) Synthesis and properties of $\mathrm{Fe}_{3} \mathrm{O}_{4}$ activated carbon magnetic nanoparticles for removal of aniline from aqueous solution: equilibrium, kinetic and thermodynamic studies. Iran J Environ Health Sci Eng 10:19. https://doi.org/10.1186/1735-2746-10-19

Khoshnamvand N, Ahmadi S, Mostafapour FK (2017) Kinetic and isotherm studies on ciprofloxacin adsorption using magnesium oxide nanoparticles. J Appl Pharm Sci 7:079-083. https://doi. org/10.7324/JAPS.2017.71112

Kilic M, Apaydin-Varol E, Putun AE (2011) Adsorptive removal of phenol from aqueous solutions on activated carbon prepared from tobacco residues: equilibrium, kinetics and thermodynamics. J Hazard Mater 189:397-403. https://doi.org/10.1016/j.jhazm at.2011.02.051

Kord Mostafapoor F, Ahmadi S, Balarak D, Rahdar S (2017) Comparision of dissolved air flotation process function for aniline and penicillin $\mathrm{G}$ removal from aqueous solutions. Hamadan Univ Med Sci 82:203-209. https://doi.org/10.21859/hums-230410

Liu P, Zhang LY (2007) Adsorption of dyes from aqueous solutions or suspensions with clay nano-adsorbents. Sep Purify Technol 58:32-39. https://doi.org/10.1016/j.seppur.2007.07.007

Mahramanliglu M, Kizilcikli I, Bicer IO (2002) Adsorption of fluoride from aqueous by acid treated spent bleaching earth. J Fluor Chem 115:41-47. https://doi.org/10.1016/s0022-1139(02)0003-9

Mahvi A, Heibati B (2009) Removal efficiency of azo dyes from textile effluent using activated carbon made from walnut wood and determination of isotherms of acid red18. Public Ardabil 1:7-15

Matsushita M, Kuramitz H, Tanaka S (2005) Electrochemical oxidation for low concentration of aniline in neutral $\mathrm{pH}$ medium: application to the removal of aniline based on the electrochemical polymerization on a carbon fiber. Environ Sci Technol 39:3805-3810. https ://doi.org/10.1021/es040379f

Mohanty K, Das D, Biswas MN (2005) Adsorption of phenol from aqueous solutions using activated carbons prepared from Tectona grandis sawdust by $\mathrm{ZnCl} 2$ activation. Chem Eng J 115:121-131. https://doi.org/10.1016/j.cej.2005.09.016

Mozafarian K, Madaeni SS, Khoshnodie M (2006) Evaluating the performance of reverse osmosis in arsenic removal from water. Water Wastewater 60:22-28

Özcan AS, Özcan A (2004) Adsorption of acid dyes from aqueous solutions onto acid-activated bentonite. J Colloid Inter Sci. 276:39-46. https://doi.org/10.1016/j.jcis.2004.03.043

Rahdar S, Ahmadi S (2017) Removal of phenol and aniline from aqueous solutions by using adsorption onto Pistacia terebinthus: study of adsorption isotherm and kinetics. J Health Res Community $2: 35-45$ 
Rahdar S, Igwegbe CA, Rahdar A, Ahmadi S (2018) Efficiency of sono-nano-catalytic process of magnesium oxide nano particle in removal of penicillin $\mathrm{G}$ from aqueous solution. Desalin Water Treat 106:330-335. https://doi.org/10.5004/dwt.2018.22102

Rahmani A, Samadi MT, Enayati MA (2008) Investigation of photocatalytic degradation of phenol through $\mathrm{UV} / \mathrm{TiO}_{2}$ process in aquatic solutions. J Res Health Sci 8:32-37

Rodrigues LA, Pinto da Silva MLC, Alvarez-Mendes MO, dos Reis Coutinho A, Thim GP (2011) Phenol removal from aqueous solution by activated carbon produced from avocado kernel seeds. Chem Eng J 174:49-57. https://doi.org/10.1016/j.cej.2011.08.027

Shen YH (2002) Removal of phenol from water by adsorption-flocculation using organic bentonite. Water Res 36:1107-1114. https ://doi.org/10.1016/s0043-1354(01)00324-4

Sui Q, Huang J, Liu Y, Chang X, Ji G, Deng S, Xie T, Yu G (2011) Rapid removal of biphenyl a on highly ordered mesoporous carbon. J Environ Sci 23:172-182. https://doi.org/10.1016/S1001 -0742(10)60391-9

Taherkhani F, Leili M, Azar MT, Faradmal J (2015) The optimization of aniline adsorption from aqueous solutions by raw bentonite and bentonite modified with cationic surfactants using the Taguchi model. Sci J Hamadan Univ Med Sci 22:55-64

Zhong W, Wang D, Xu X, Luo Q, Wang B, Shan X, Wang Z (2010) Screening level ecological risk assessment for phenols in surface water of the Taihu Lake. Chemosphere 80:998-1005. https://doi. org/10.1016/j.chemosphere.2010.05.036

Publisher's Note Springer Nature remains neutral with regard to jurisdictional claims in published maps and institutional affiliations. 